ISSN 2089-8673

Jurnal Nasional Pendidikan Teknik Informatika (JANAPATI)

Volume 1, Nomor 2, Juli 2013

\title{
PENGEMBANGAN APLIKASI PEMBUATAN POLA MOTIF BATIK DENGAN MENGGUNAKAN PENGOLAHAN CITRA DIGITAL
}

\section{Oleh}

\author{
I Putu Wandra Adnyana ${ }^{1}$, Made Windu Antara Kesiman², Dessy Seri \\ Wahyuni \\ Jurusan Pendidikan Teknik Informatika \\ Universitas Pendidikan Ganesha \\ Email: wandra.adnyana@gmail.com ${ }^{1}$, dekndu@yahoo.com²
}

\begin{abstract}
ABSTRAK
Batik merupakan suatu kebudayaan nasional asli milik Negara Indonesia. Ciri khas kain batik adalah memiliki berbagai jenis motif yang dibuat sedemikian rupa sehingga memiliki nilai jual yang tinggi di kalangan masyarakat. Namun permasalahannya disini, banyak industri batik menengah kebawah yang masih kesulitan di dalam pembuatan pola motif batiknya. Motif yang dibuat biasanya dibuat secara manual yang dipesan dari seorang desain grafis dari luar dan tentunya memakan waktu lama dan biaya produksi yang cukup besar.

Di era komputerisasi seperti saat ini, perlu adanya teknologi yang mampu untuk membantu mempermudah pembuatan motif batik dan melestarikan kebudayaan asli milik kita ini namun tidak mengurangi makna dari batik itu sendiri. Maka dibuatlah suatu media yakni berupa aplikasi pembuatan pola motif batik. Aplikasi ini dibuat berbasis desktop dan menggunakan beberapa metode pengolahan citra digital. Tujuan aplikasi ini adalah membantu para pembatik untuk membuat pola motif batiknya sendiri dengan mudah dan efisien.

Hasil analisis, implementasi, dan pengujian pada penelitian ini adalah suatu Aplikasi Pembuatan Pola Motif Batik yang diimplementasikan menggunakan bahasa pemrograman Delphi. Dari data hasil angket uji coba pembuatan pola motif batik didapat bahwa sebagian besar motif batik yang diolah mampu atau layak untuk dikomersialkan. Berdasarkan hasil tersebut, Aplikasi Pembuatan Pola Motif Batik sangat membantu di dalam pembuatan pola motif batik oleh pengusaha batik sebelum akhirnya dicetak menjadi kain batik.
\end{abstract}

Kata Kunci: Pola Motif, Batik, Citra Digital.

\section{Pendahuluan}

Indonesia merupakan negara yang kaya akan keanekaragaman budaya dan kesenian daerahnya. Keanekaragaman budaya dan kesenian daerah di Indonesia tersebut telah dikenal hingga ke mancanegara. Salah satu contoh dari kesenian daerah itu adalah kesenian batik. Batik merupakan salah satu bentuk kesenian tradisi yang dari hari ke hari semakin menampakkan jejak kebermaknaannya dalam kebudayaan Indonesia. Batik yang juga dikenal sebagai kesenian lukis atau pewarnaan pada kain untuk pembuatan busana itu memiliki nilai yang tinggi terhadap budaya Indonesia. 
Batik memiliki ciri khas tersendiri bagi pemakainya, karena itu sebagian besar orang-orang memakai batik pada kegiatan formal maupun nonformal. Pada proses pembuatan batik hal yang pertama yang perlu diperhatikan adalah pola motif. Pola motif batik sangat penting guna menambah daya tarik batik itu sendiri.

Permasalahan disini adalah pada umumnya perusahaan pembuatan batik khususnya perusahaan batik menengah kebawah belum memaksimalkan teknologi yang ada pada saat ini dalam pembuatan Pola motif batik. Seperti contohnya menurut penuturan pemilik suatu perusahan batik yaitu Bapak Ali yang memiliki sebuah perusahan batik bernama "Alisa Batik" yang beralamat di Jalan Pulau Bungin Gang Perbatasan No. 17 Denpasar-Bali. Bapak Ali sendiri mengatakan bahwa dalam membuat pola motif itu, ia harus mengeluarkan biaya tambahan yaitu dengan memesan pembuatan suatu motif batik pada perusahan atau rumah produksi yang bergerak di bidang desain grafis.

Berdasarkan permasalahan di atas, peneliti tertarik untuk mengembangkan suatu perangkat lunak dimana fungsinya untuk membantu dalam pembuatan pola motif batik bagi pengusaha batik khususnya pada pengusaha batik menengah ke bawah. Salah satu media alternatif yang mungkin dibuat, yaitu berupa perangkat lunak pembuatan pola motif batik dengan menggunakan pengolahan citra digital. Perangkat lunak ini diharapkan setidaknya dapat mengurangi beban biaya tambahan khususnya bagi industri batik menengah ke bawah yaitu dengan cara yang cukup sederhana, tinggal memasukkan gambar yang ingin dibuatkan motif batik ke dalam perangkat lunak, dan perangkat lunak itu sendiri yang akan mengolah gambar tersebut dan memperoleh hasil akhir berupa sebuah pola motif batik, sehingga pengusahan batik mampu untuk mengolahnya sendiri tanpa adanya bantuan dari seorang desain grafis.

Berdasarkan latar belakang masalah yang telah diuraikan di atas dapat diketahui pokok permasalahan yang dihadapi adalah bagaimana rancangan dan implementasi Aplikasi Pembuatan Pola Motif Batik dengan menggunakan pengolahan citra digital. Adapun tujuan yang ingin dicapai dalam penelitian skripsi ini adalah merancang dan mengimplementasikan Aplikasi Pembuatan Pola Motif Batik dengan menggunakan pengolahan citra digital. Batasan masalah dari pengembangan Aplikasi Pembuatan Pola Motif Batik dengan menggunakan pengolahan citra digital ini adalah format citra input berekstensi bitmap (*.bmp).

\section{Kajian Pustaka}

Aplikasi Pembuatan Pola Motif Batik ini merupakan suatu aplikasi yang dibuat dari metode pengolahan citra digital. Setiap gambar dapat dibuat menjadi suatu motif batik dengan cara gambar tersebut diolah sedemikian rupa dengan bantuan beberapa metode pengolahan citra digital. Alasan dilakukannya pengolahan citra pada citra digital adalah untuk mendapatkan sebuah citra baru dari hasil citra yang diinputkan secara langsung oleh user. Citra yang diinputkan oleh user akan membentuk sebuah output citra baru dimana citra yang diinputkan itu diproses sehingga menjadi sebuah pola motif batik. Metode pengolahan citra digital yang dimaksud adalah antara lain: operasi geometri yang terdiri dari percerminan (flipping), ada dua jenis pencerminan yang digunakan yaitu pencerminan secara vertikal dan horisontal. Rotasi/pemutaran (rotating), terdapat dua jenis rotasi/pemutaran yaitu rotasi searah dengan jarum jam dan berlawanan 
dengan jarum jam yang masing-masing memiliki sudut rotasi $90^{\circ}$ dan $180^{\circ}$. Penskalaan (scaling/zooming) yaitu metode pengolahan citra untuk memperbesar atau memperkecil ukuran citra. Selain operasi geometri tersebut juga terdapat beberapa metode lain seperti Image Negative. Image Negatif pada citra digital merupakan suatu metode pengolahan citra yaitu dimana untuk menukar atau membalikkan warna hitam menjadi putih dan putih menjadi hitam pada citra hitam putih. Image Blending, yaitu merupakan penggabungan citra dilakukan dengan cara menimpakan sebuah citra pada citra yang lain. Dengan kata lain dilakukan operasi penjumlahan terhadap citra yang ada dengan pemberian bobot pada masing-masing citra. Threshold digunakan untuk mengubah citra dengan format skala keabuan, yang mempunyai kemungkinan nilai lebih dari 2 ke citra biner yang memiliki 2 buah nilai (yaitu 0 dan 1). Rekursif adalah salah satu metode dalam dunia matematika dimana definisi sebuah fungsi mengandung fungsi itu sendiri. Dalam dunia pemrograman, rekursi diimplementasikan dalam sebuah fungsi yang memanggil dirinya sendiri. Brightness, pada dasarnya brightness mengubah nilai keabuan/warna dari gelap menuju terang atau sebaliknya merubah citra yang terlalu cemerlang/pucat menjadi gelap.

Sebuah pola motif batik dibuat dari gabungan metode-metode pengolahan citra digital di atas. Setiap polanya dibuat berdasarkan gabungan metode yang berbeda (dikreasikan). Sehingga pola motif yang satu dengan pola yang lainnya memiliki fungsi atau gabungan metode yang berbeda-beda. Misalnya motif satu hanya menggunakan metode pencerminan dan rotasi, motif berikutnya menggunakan gabungan dari metode lainnya, begitu seterusnya.

Pembuatan pola motif batik ini dikelompokkan menjadi dua, yaitu motif batik variasi yang merupakan pola motif batik yang bentuk polanya tergantung pada citra input (berubah-ubah sesuai bentuk citra inputnya) dan motif batik fraktal yang merupakan pola motif batik yang bentuk polanya tetap (sudah dibuat sedemikian rupa), sehingga apapun bentuk dari citra yang diinputkan hasilnya tetap memiliki satu jenis pola. Masing-masing dari kedua bentuk pola motif itu memiliki 14 pilihan motif, jadi pengusaha batik dapat memilih 14 jenis batik yang berbeda-beda dari setiap gambar dan 14 jenis batik yang memiliki pola yang sama.

\section{Analisis dan Perancangan}

\subsection{Analisis Masalah dan Usulan Solusi}

Berdasarkan analisis dari cara terdahulu dalam pembuatan pola motif batik, terdapat beberapa masalah yang menjadi kelemahan adalah dalam pembuatan pola motif batik, pengusaha batik masih mengandalkan jasa dari desain grafis luar dalam membuat sebuah pola motif batik sehingga pengusaha batik mengeluarkan biaya yang lebih banyak dalam memproduksi sebuah batik. Serta keterbatasannya pola motif yang ingin dibuat oleh pembatik itu sendiri.

Berdasarkan analisis masalah di atas maka solusi yang dapat diusulkan adalah sebuah perangkat lunak Aplikasi Pembuatan Pola Motif Batik. Solusi yang dapat diusulkan dari perangkat lunak ini adalah Pengusaha batik tidak perlu lagi untuk menggunakan jasa desain grafis luar dalam pembuatan pola motif batik, karena Pengusaha Batik sendiri pun nantinya dapat menggunakan sistem ini dengan mudah tentunya dengan berbantuan komputer saja. Serta Variasi batik yang 
dihasilkan lebih beragam, karena gambar yang telah diolah akan dapat diolah kembali menjadi motif lain dan begitu seterusnya.

\subsection{Analisis Perangkat Lunak}

Secara umum, perangkat lunak aplikasi pembuatan pola moti batik diharapkan memiliki beberapa fungsi utama yaitu melakukan operasi geometri, menghasilkan Image Negative, Rekursif, brightness, menggabungkan citra, dan pewarnaan background.

Tujuan dari pengembangan perangkat lunak ini adalah dapat melakukan operasi geometri, dapat menghasilkan Image Negative, Rekursif, brightness, menggabungkan citra, dan pewarnaan background.

Masukan dari aplikasi ini adalah file citra bertipe bitmap (*.bmp) yaitu terdapat pada citra input 1 dan citra input 2 . Keluarannya adalah citra output bertipe bitmap (*.bmp) berupa pola motif batik, informasi citra input dan output, serta about (informasi tentang aplikasi dan peneliti).

\subsection{Perancangan Perangkat Lunak}

Batasan perancangan perangkat lunak Aplikasi Pembuatan Pola Motif Batik yang akan dibuat ini adalah format citra input berekstensi bitmap (*.bmp). Perancangan arsitektur perangkat lunak menggambarkan bagian-bagian modul, struktur ketergantungan antar modul, dan hubungan antar modul dari perangkat lunak yang dibangun. Pada bagian ini terdapat diagram konteks atau Data Flow Diagram (DFD) Level 0 dan structure chart sebagai kendali fungsional yang digambarkan seperti Gambar 2 dan Gambar 3 untuk perangkat lunak Aplikasi Pembuatan Pola Motif Batik.

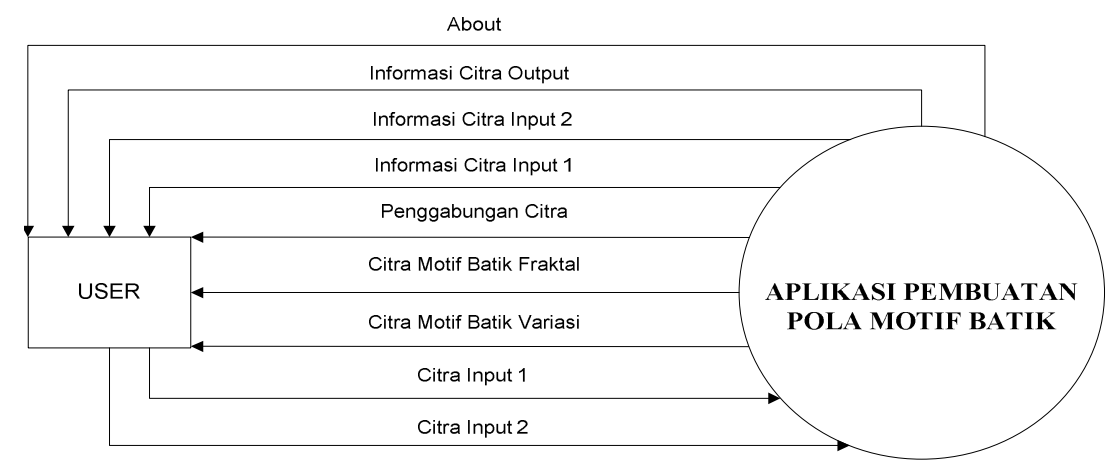

Gambar 1 Diagram Konteks Perangkat Lunak Aplikasi Pembuatan Pola Motif Batik 


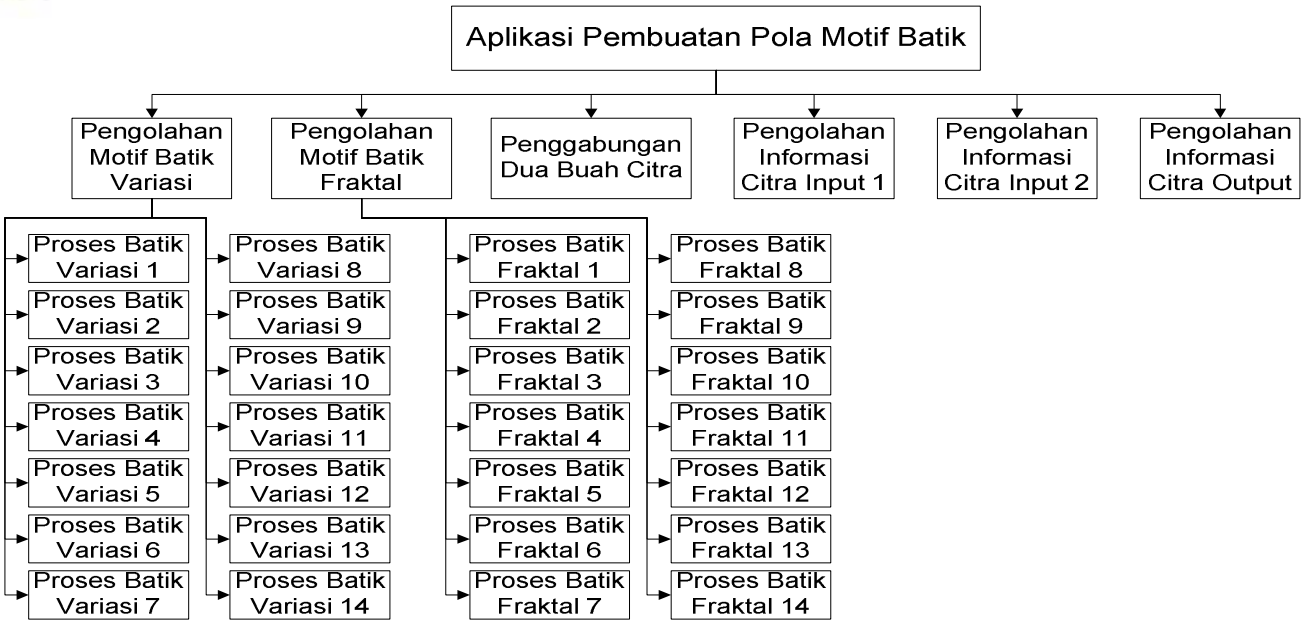

Gambar 2 Structure Chart Perangkat Lunak Aplikasi Pembuatan Pola Motif Batik

\section{Implementasi dan Pengujian}

\subsection{Implementasi Perangkat Lunak}

Data Flow Diagram (DFD) dan Rancangan Arsitektur Perangkat Lunak Aplikasi Pembuatan Pola Motif Batik diimplementasikan dengan menggunakan bahasa pemrograman Delphi 7. Berikut ini pemetaan unit serta tampilan Form Utama dari Aplikasi Pembuatan Pola Motif Batik.

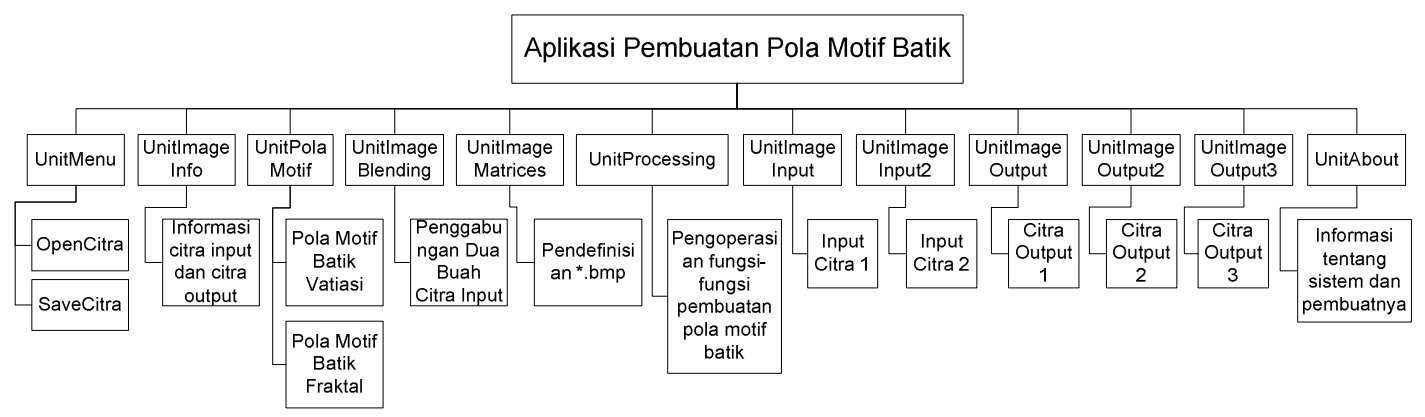

Gambar 3 Pemetaan Unit Aplikasi Pembuatan Pola Motif Batik

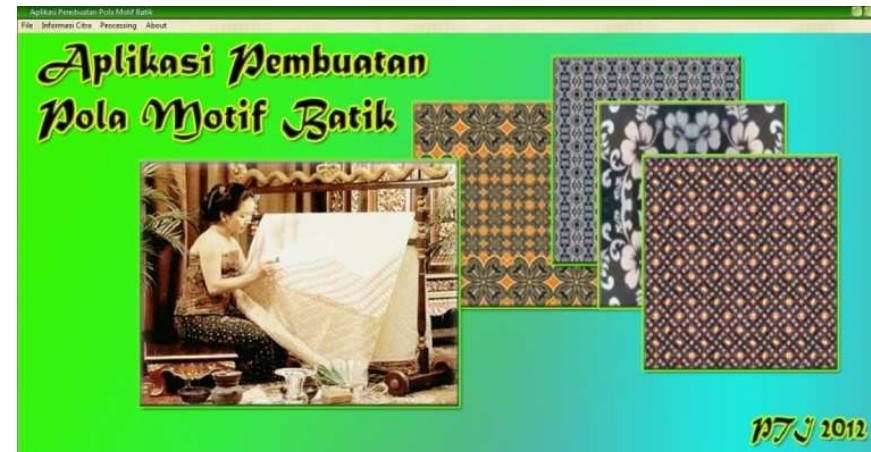

Gambar 4 Implementasi Form Utama Aplikasi Pembuatan Pola Motif Batik 

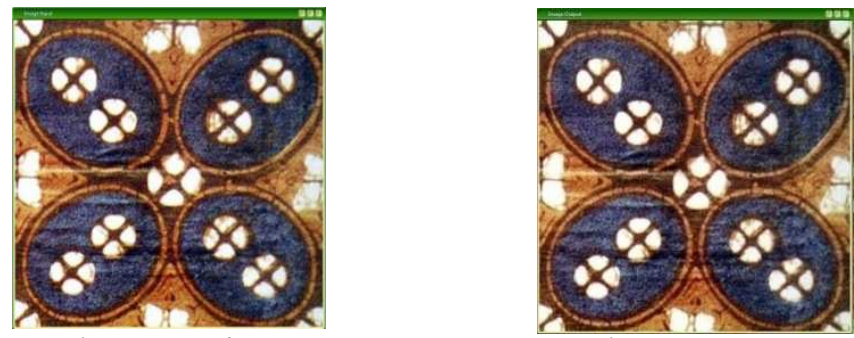

Gambar 5 Implementasi Form Image Input dan Form Image Output Aplikasi Pembuatan Pola Motif Batik

\begin{tabular}{|l|}
\hline \multicolumn{1}{|c|}{ Informasi Citra } \\
\hline Image Tipe : Color Image \\
Color Depth : $\mathbf{2 4}$ bits/pixel = $\mathbf{3}$ Bytes/pixel \\
Pixel Size $: \mathbf{8 0 0 x 8 0 0 p i x e l ~}$
\end{tabular}

Gambar 6 Implementasi Form Informasi Citra

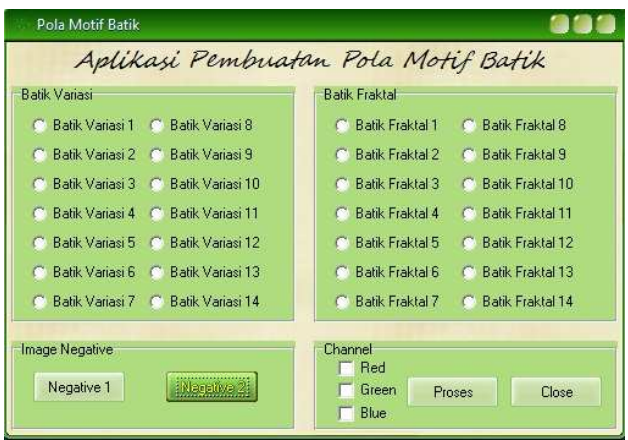

Gambar 7 Implementasi Form Pola Motif Batik

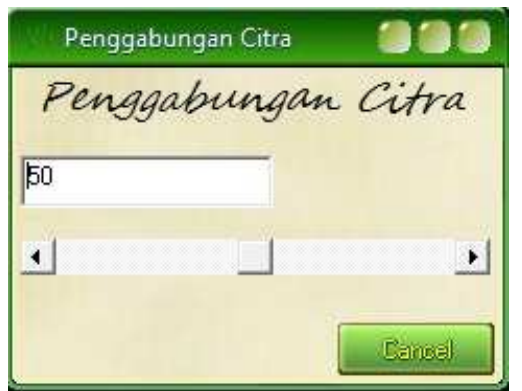

Gambar 8 Implementasi Form Pola Motif Batik

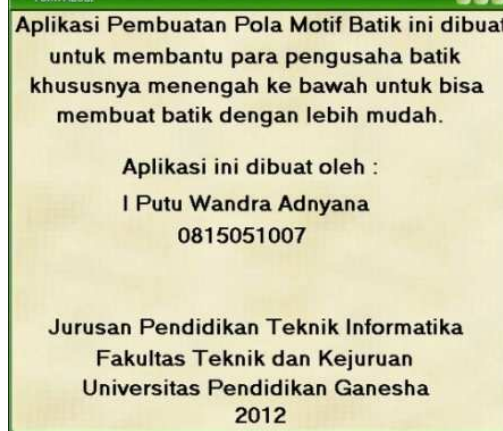

Gambar 9 Implementasi Form Pola Motif Batik 


\subsection{Pengujian Perangkat Lunak}

Pengujian perangkat lunak Aplikasi Pembuatan Pola Motif Batik ini dilakukan langsung oleh pembuat batik untuk uji kelayakan motif batiknya. Pengujian perangkat lunak untuk uji coba pembuatan pola motif batik dilakukan pada tanggal 29 Mei 2012 oleh para pembuat batik Alisa Batik Denpasar, dimana pembuat batik yang dimintai bantuannya berjumlah 2 orang. Sebelum memuli proses pengujian perangkat lunak, penulis menginformasikan kepada pembatik tentang alur dari aplikasi serta memperkenalkan tombol-tombol yang bisa mereka akses untuk menjalankan suatu fungsi tertentu. Usai memberikan informasi, penulis kemudian mempersilakan pembuat batik untuk menggunakan atau menjalankan Aplikasi Pembuatan Pola Motif Batik ini. Kemudian setelah diujicobakan, pembuat batik mengisi angket yang telah diberikan. Berikut data rekapitulasi hasil pengujian uji coba pembuatan pola motif batik yang dilakukan oleh pembuat batik pada tanggal 29 Mei 2012.

Tabel 1 Data Rekapitulasi Hasil Pengujian Pembuatan Pola Motif Batik

\begin{tabular}{|c|c|c|c|c|c|c|c|c|c|c|c|c|c|c|c|c|c|}
\hline \multirow{2}{*}{$\begin{array}{c}\text { Pembuat } \\
\text { Batik }\end{array}$} & \multirow{2}{*}{$\begin{array}{l}\text { Citra } \\
\text { Input }\end{array}$} & \multirow{2}{*}{$\begin{array}{c}\text { Pola Motif } \\
\text { Batik }\end{array}$} & \multicolumn{14}{|c|}{ Kelayakan Dikomersialkan (Y/T) } & \multirow{2}{*}{$\begin{array}{c}\text { Hasil } \\
\text { Perbandingan }\end{array}$} \\
\hline & & & 1 & 2 & 3 & 4 & 5 & 6 & 7 & 8 & 9 & 10 & 11 & 12 & 13 & 14 & \\
\hline \multirow[t]{7}{*}{ Ali Ghatur } & \multirow[t]{2}{*}{ motifl } & Variasi & $\mathrm{Y}$ & $\mathrm{Y}$ & $\mathrm{Y}$ & $\mathrm{Y}$ & $\mathrm{Y}$ & $\mathrm{Y}$ & $\mathrm{Y}$ & $\mathrm{Y}$ & $\mathrm{Y}$ & $\mathrm{Y}$ & $\mathrm{Y}$ & $\mathrm{Y}$ & $\mathrm{Y}$ & $\mathrm{Y}$ & \multirow{14}{*}{ Sama } \\
\hline & & Fraktal & $\mathrm{Y}$ & $\mathrm{Y}$ & $\mathrm{Y}$ & $\mathrm{T}$ & $\mathrm{Y}$ & $\mathrm{Y}$ & $\mathrm{Y}$ & $\mathrm{Y}$ & $\mathrm{T}$ & $\mathrm{Y}$ & $\mathrm{Y}$ & $\mathrm{Y}$ & $\mathrm{Y}$ & $\mathrm{Y}$ & \\
\hline & daun3 & Variasi & $\mathrm{Y}$ & $\mathrm{Y}$ & $\mathrm{Y}$ & $\mathrm{Y}$ & $\mathrm{Y}$ & $\mathrm{Y}$ & $\mathrm{Y}$ & $\mathrm{Y}$ & $\mathrm{Y}$ & $\mathrm{Y}$ & $\mathrm{T}$ & $\mathrm{Y}$ & $\mathrm{Y}$ & $\mathrm{Y}$ & \\
\hline & motif11 & Variasi & $\mathrm{Y}$ & $\mathrm{Y}$ & $\mathrm{Y}$ & $\mathrm{Y}$ & $\mathrm{Y}$ & $\mathrm{T}$ & $\mathrm{Y}$ & $\mathrm{Y}$ & $\mathrm{Y}$ & $\mathrm{Y}$ & $\mathrm{Y}$ & $\mathrm{Y}$ & $\mathrm{Y}$ & $\mathrm{Y}$ & \\
\hline & $\mathrm{r}$ & Variasi & $\mathrm{Y}$ & $\mathrm{Y}$ & $\mathrm{T}$ & $\mathrm{Y}$ & $\mathrm{Y}$ & $\mathrm{Y}$ & $\mathrm{Y}$ & $\mathrm{Y}$ & $\mathrm{Y}$ & $\mathrm{Y}$ & $\mathrm{T}$ & $\mathrm{Y}$ & $\mathrm{Y}$ & $\mathrm{Y}$ & \\
\hline & $\begin{array}{l}\text { batik19 } \\
\text { batik3 }\end{array}$ & $\begin{array}{c}\text { Penggabungan } \\
\text { Citra }\end{array}$ & \multicolumn{14}{|c|}{$\mathrm{Y}$} & \\
\hline & Lena512 & $\begin{array}{l}\text { Pewarnaan } \\
\text { Backgound }\end{array}$ & \multicolumn{14}{|c|}{$\mathrm{Y}$} & \\
\hline \multirow{7}{*}{$\begin{array}{l}\text { Ima Tri } \\
\text { Setiani }\end{array}$} & \multirow[t]{2}{*}{ motifl } & Variasi & $\mathrm{Y}$ & $\mathrm{Y}$ & $\mathrm{Y}$ & $\mathrm{Y}$ & $\mathrm{Y}$ & $\mathrm{Y}$ & $\mathrm{Y}$ & $\mathrm{Y}$ & $\mathrm{Y}$ & $\mathrm{Y}$ & $\mathrm{Y}$ & $\mathrm{Y}$ & $\mathrm{Y}$ & $\mathrm{Y}$ & \\
\hline & & Fraktal & $\mathrm{Y}$ & $\mathrm{Y}$ & $\mathrm{Y}$ & $\mathrm{T}$ & $\mathrm{Y}$ & $\mathrm{Y}$ & $\mathrm{Y}$ & $\mathrm{Y}$ & $\mathrm{T}$ & $\mathrm{Y}$ & $\mathrm{Y}$ & $\mathrm{Y}$ & $\mathrm{Y}$ & $\mathrm{Y}$ & \\
\hline & daun3 & Variasi & $\mathrm{Y}$ & $\mathrm{Y}$ & $\mathrm{Y}$ & $\mathrm{Y}$ & $\mathrm{Y}$ & $\mathrm{Y}$ & $\mathrm{Y}$ & $\mathrm{Y}$ & $\mathrm{Y}$ & $\mathrm{Y}$ & $\mathrm{T}$ & $\mathrm{Y}$ & $\mathrm{Y}$ & $\mathrm{Y}$ & \\
\hline & motif11 & Variasi & $\mathrm{Y}$ & $\mathrm{Y}$ & $\mathrm{Y}$ & $\mathrm{Y}$ & $\mathrm{Y}$ & $\mathrm{T}$ & $\mathrm{Y}$ & $\mathrm{Y}$ & $\mathrm{Y}$ & $\mathrm{Y}$ & $\mathrm{Y}$ & $\mathrm{Y}$ & $\mathrm{Y}$ & $\mathrm{Y}$ & \\
\hline & $\mathrm{r}$ & Variasi & $\mathrm{Y}$ & $\mathrm{Y}$ & $\mathrm{T}$ & $\mathrm{Y}$ & $\mathrm{Y}$ & $\mathrm{Y}$ & $\mathrm{Y}$ & $\mathrm{Y}$ & $\mathrm{Y}$ & $\mathrm{Y}$ & $\mathrm{T}$ & $\mathrm{Y}$ & $\mathrm{Y}$ & $\mathrm{Y}$ & \\
\hline & $\begin{array}{l}\text { batik19 } \\
\text { batik3 }\end{array}$ & $\begin{array}{c}\text { Penggabungan } \\
\text { Citra }\end{array}$ & \multicolumn{14}{|c|}{$\mathrm{Y}$} & \\
\hline & Lena512 & $\begin{array}{l}\text { Pewarnaan } \\
\text { Backgound }\end{array}$ & \multicolumn{14}{|c|}{$\mathrm{Y}$} & \\
\hline
\end{tabular}

Berdasarkan data rekapitulasi hasil pengujian uji coba pola motif batik yang diisi oleh pembuat batik Alisa Batik Denpasar maka diperoleh informasi bahwa hasil pengolahan pola motif batik dari citra inputan yang berbeda-beda terlihat jelas bahwa secara keseluruhan menempati tempat layak untuk dikomersialkan (tanda "Y"), tetapi untuk beberapa motif ada beberapa yang menempati tempat tidak layak untuk dikomersialkan (tanda "T"). Namun pola motif yang tidak layak tersebut bukan berarti tidak layak secara keseluruhan, hanya saja menurut pembuat batik, motif tersebut tidak layak untuk dijadikan bahan dasar baju, tetapi masih bisa jika dialihkan fungsinya untuk dijadikan bahan dasar seprai dan sarung.

Berikut merupakan hasil salah satu pengujian pola motif batik yang menurut pembatik sendiri dapat dikomersialkan (motif1 pada batik variasi). 
ISSN 2089-8673

Jurnal Nasional Pendidikan Teknik Informatika (JANAPATI)

Volume 1, Nomor 2, Juli 2013
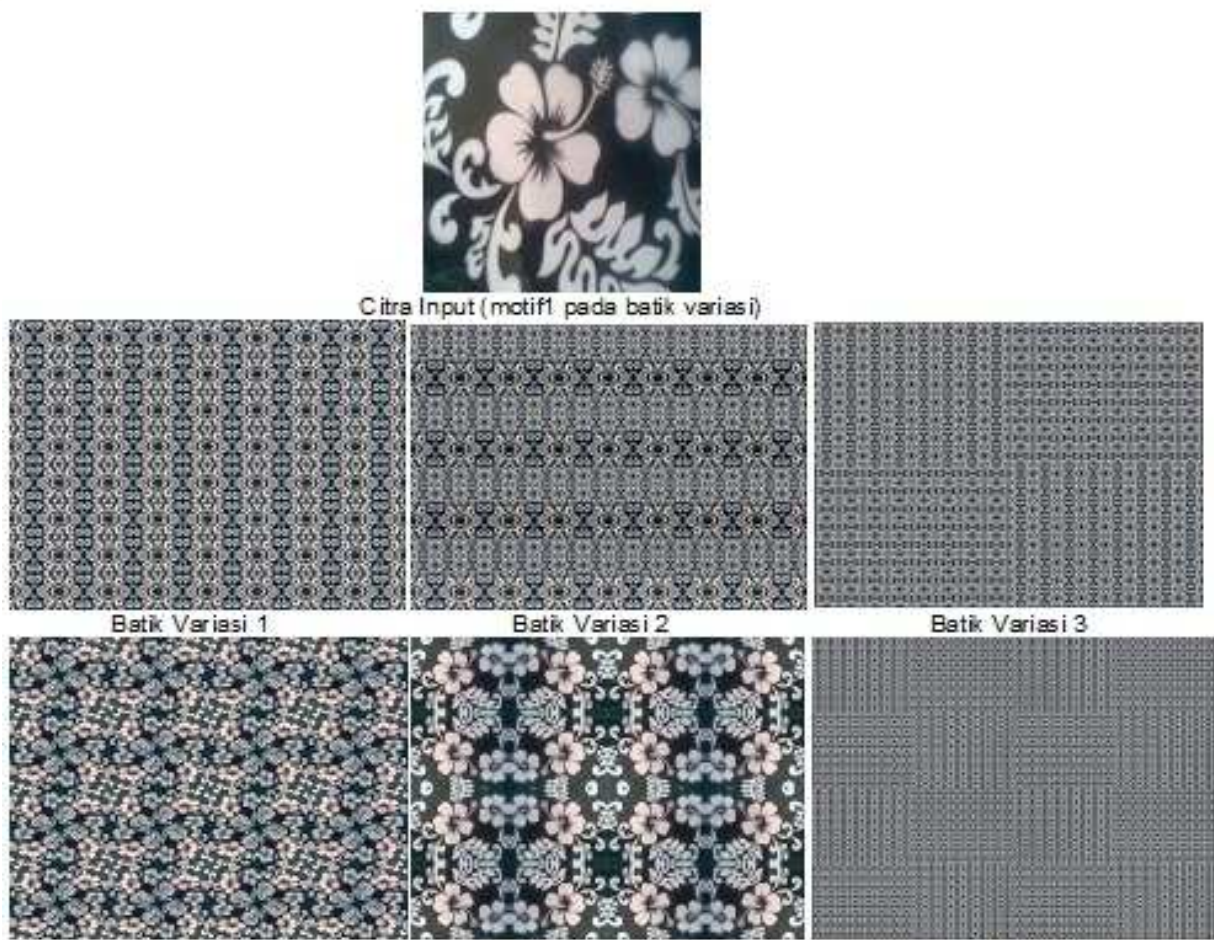

Batik Variasi
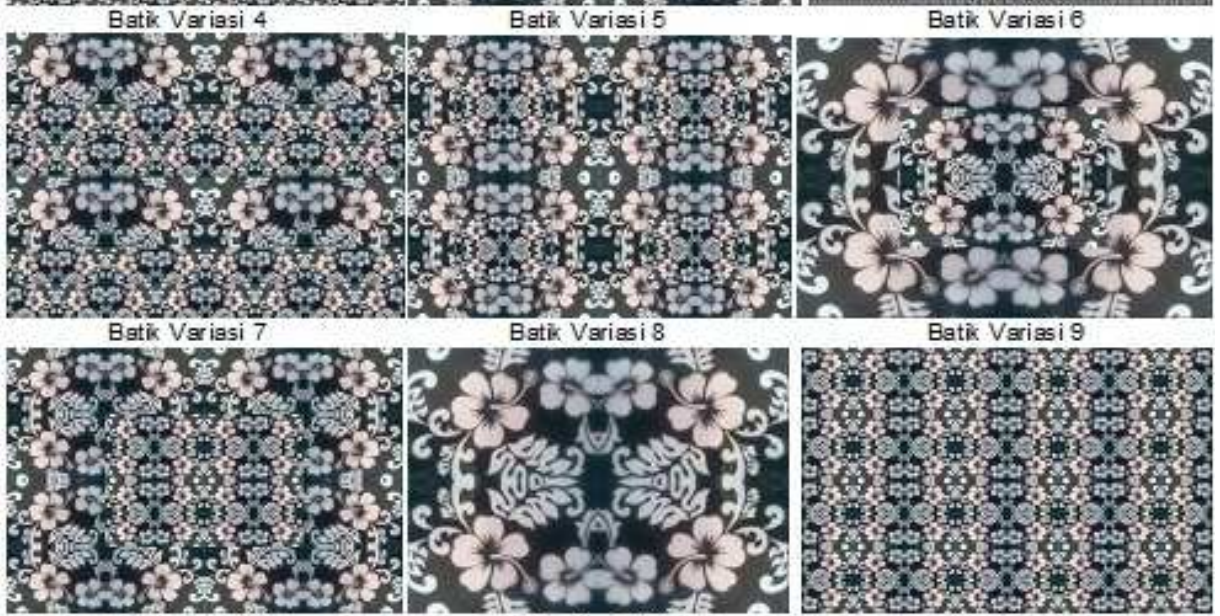

Batí Variasi 8

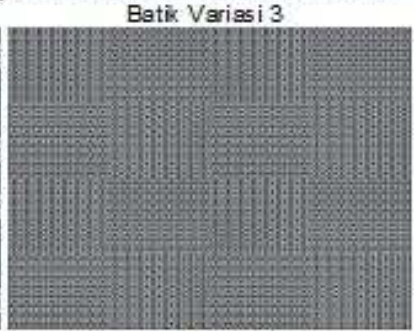

Batik Variasi 8

Batik Variasi 10
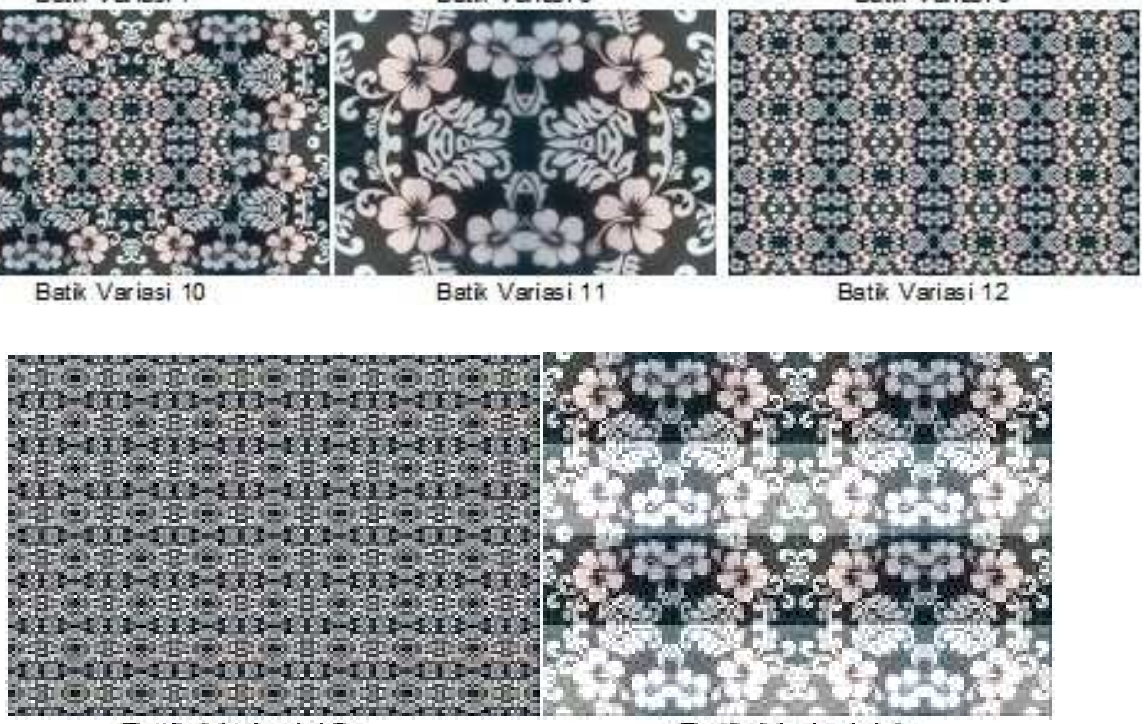

Batik Variasi 13

Batik Variasi 14 
V. Penutup

\subsection{Simpulan}

Berdasarkan hasil analisis, implementasi dan pengujian pada penelitian ini, maka dapat diambil simpulan bahwa Aplikasi Pembuatan Pola Motif Batik diimplementasikan menggunakan bahasa pemrograman Borland Delphi 7.0 dengan menggunakan 6 jenis metode, yaitu operasi geometri (image rotation, image flip, zoom, shrink), image negative, image blending, threshold, rekursif, dan Brightness. Dan dari data hasil angket uji coba pembuatan pola motif batik didapat bahwa sebagian besar motif batik yang diolah mampu atau layak untuk dikomersialkan. Dalam hal ini, Aplikasi Pembuatan Pola Motif Batik sangat membantu di dalam pembuatan pola motif batik oleh pengusaha batik sebelum akhirnya dicetak menjadi kain batik. Sehingga pembuat batik dapat dengan mudah membuat motifnya sendiri yang mereka anggap memiliki nilai jual tinggi tanpa harus mengeluarkan biaya tambahan di dalam pembuatan desain motifnya.

\subsection{Saran}

Berdasarkan pengamatan penulis, disarankan bagi pembaca yang ingin mengembangkan aplikasi ini agar dapat mengembangkan aplikasi ini dengan format input yang tidak dibatasi lagi sehingga semua format citra dapat dieksekusi oleh sistem, mengembangkan aplikasi ini dengan menggunakan berbagai metode tambahan lainnya sehingga menghasilkan hasil pola motif yang lebih banyak dan beragam, dan proses pembuatan pola motif ini tidak hanya sebatas membuat pola motif batik saja tetapi dapat juga diimplementasikan ke bentuk songket maupun pembuatan sarung dan kamben.

\section{Daftar Pustaka}

BMP File Format. http://en.wikipedia.org/wiki/BMP file format (diakses tgl 26 Nopember 2011).

Gonzales, R. C., Woods, R.E, and Eddins, S.L. 2002. Digital Image Processing Using MATLAB. India: Pearson Education.

Rinjani, Ni Made Ayu Gunung. 2011. Studi Implementatif Digitalisasi Dan Restorasi Citra Digital Lontar Kuno Bali. Skripsi (tidak diterbitkan). Jurusan Pendidikan Teknik Informatika, Undiksha Singaraja.

Hamidin, Asep S. 2010. Batik Warisan Budaya Asli Indonesia. Yogyakarta: Narasi.

Malik, Jaja Jamaludin. 2005. Tip \& Trik Unik Delphi. Yogyakarta: Penerbit Andi. ------, 2006. Tip \& Trik Unik Delphi Lanjutan. Yogyakarta: Penerbit Andi.

Munir, Rinaldi. 2004. Pengolahan Citra Digital dengan Pendekatan Algoritmik. Bandung: Penerbit Infomatika Bandung.

Pujianto. 2007. Trik Pemrograman Delphi 8.0. Jakarta: Penerbit Elex Media Komputindo.

Putra, Darma. 2010. Pengolahan Citra Digital. Yogyakarta: Penerbit Andi.

Kesiman, Made Windu Antara. 2010. Image Processing Modul with Delphi. Penelitian (tidak diterbitkan). Jurusan Pendidikan Teknik Informatika, Undiksha Singaraja. 